\title{
MENGGAGAS BISNIS ISLAM DALAM PEREKONOMIAN MODERN
}

\author{
Oleh : M. Noor Asnawi
}

\begin{abstract}
ABSTRAK
Dalam dunia global saat ini, ekonomi tampil seolah menjadi panglima. Banyak para pelaku ekonomi melakukan berbagai terosoban dalam mengembangkan dunia bisnis. Yang menarik, pada saat ini pula, beberapa ekonom muslil juga gencara melakukan terobosan bisnis altematif yang disebut Bisnis Islam yaitu adalah bisnis yang dikendalikan oleh nilai - nilai normatif ajaran Islam, baik dari cara perolehannya maupun cara pendayagunaannya Dalam pandangan Islam, dalam melakukan aktivitas bisnisnya, walaupun ada nilai - nilai kebebasan, nilai kepemilikan, dan kesamaan semuanya itu ada batas dan wilayah yang sudah ditentukan. Madjid Fakhri, dalam tulisannya Etika Dalam Islam (1995), ia katakan bahwa Bisnis islami yang dikendalikan oleh aturan halal dan haram, sama sekali beda dengan bisnis yang non islami. Dengan berlandaskan pada asas sekularisme yang bersendikan nilai - nilai materiil, bisnis non islami tidaklah memperhatikan halal - dan haram dalam merealisasikan tujuan bisnisnya.
\end{abstract}

Kata Kunci; gagas, bisnis, Islam, Ekonomi Modem

\section{A. Pengantar.}

Islam sebagai agama yang diwahyukan kepada Nabi Muhammad SAW, adalah mata rantai terakhir agama Allah yang diwahyukan kepada semua rosulnya dan kepada seluruh umat manusia sepanjang zaman, hingga datangnya hari kiamat nanti. Sebagai agama Allah yang telah disempurnakan, Islam memberi pedoman dalam seluruh aspek kehidupan manusia, yang menyangkut idiologi, sosial, politik, maupun perekonomian. Agar manusia dalam melakukan aktifitas dimuka bumi ini senantiasa didasarkan pada norma -norma yang telah diajarkan (Azhar, 1978).

Aktifitas manusia di muka bumi menuntut berbagai macam kebutuhan dalam rangka mempertahankan kelangsungan hidupnya. Ada yang beraktivitas di bidang sektor pertanian, perkebunan, perdagangan, perpolitikan dll. Semuanya itu dalam rangka untuk memenuhi kebutuhan dan kelangsungan dalam hidupnya. Sejak zaman Rosul Muhammad SAW, umat islam telah menggeluti pekerjaan sesuai dengan

- Penulis adalah dosen Fakultas Ekonomi den Mirekar PKPBA UIIS Malong 
profesi yang dimiliki. Banyak diantara para sahabat yang menjadi pengusaha besar dan melakukan ekspansi bisnisnya sampai melewati batas teritorial Mekah ataupun Madinah. Para sahabat sangat menguasai hal - hal yang terkait dengan perdagangan di saat itu, baik yang menyangkut masalah transaksi hubungan perdagangan, ataupun terkait dengan manajemen dalam usaha yang di bangunnya, (Afzalurrahman, 1987).

Seiring dengan perjalanan waktu, semakin majunya dunia perdagangan dan bisnis, orang semakin tergiur dengan berbagai macam teori, sistem dan cara - cara baru dalam dunia perdagangan dan bisnis agar bagaimana modal sedikit yang dimiliki cepat mendapatkan hasil banyak, walaupun bertentangan dengan nilai - nilai normatif transendental yang kita yakini. Namun lama - kelamaan kalau keyakinan ini telah melembaga dalam nurani pelaku bisnis, niscaya akan mengkikis habis nilai - nilai normatif yang dibangun oleh islam. (Azhar Basyir, 1978). Seiring dengan munculnya paradigma islamisasi ilmu pengetahuan termasuk didalamnya ekonomi, penulis ingin mengkritisi, menggali serta mengembalikan nilai-nilai syariat dalam dunia bisnis, dan menampilkan wajah baru, dengan kemasan syariat islam.

\section{B. Pengertian Bisnis.}

Setiap manusia memerlukan harta untuk mencukupi segala kebutuhan dalam hidupnya, yang dilakukan dengan berbagai macam cara dalam rangka untuk mendapatkan harta dan kekayaan. Salah satu cara untuk memenuhi kebutuhan adalah dengan bekerja yang diantara pekerjaan itu ada yang dinamakan bisnis. Bisnis merupakan pertukaran barang, jasa, atau uang yang saling menguntungkan atau memberi manfaat (Skinner, 1992). Menurut J. S. Nimpoena (1995), pengertian bisnis dapat dibedakan menjadi dua macam, pengertian bisnis secara sempit dan luas. Pengertian sempit, bisnis adalah fiksi, dalam pengertian luas bisnis sangat terkait dengan perekonomian dan politik. Bisnis dalam kamus Bahasa Indonesi di artikan usaha komersial di bidang perdagangan, dan bidang usaha. Panji Anoraga (1995) mendefinisikan bisnis adalah "The brying and selling of good and services" . Dalam pandangan Straub dan Atter sebagaimana dikutip oleh Ismail Yusanto, mendefinisikan dengan jelas yang dinamakan bisnis adalah suatu organisasi yang menjalankan aktifitas produksi serta penjualan barang dan jasa yang diinginkan oleh konsumen untuk memperoleh profit, (Yusanto, 1987).

Adapun yang dinamakan bisnis islami, adalah sebagaimana yang sering tergambarkan dalam al quran surat Ibrahim : $(32-34)$, (al A'raf, 10), (Huud 61). Diantara gambaran bisnis yang tertuang dalam al quran itu mengandung makna anjuran seseorang untuk mencari rizki disaat ia mengarungi bahtera kehidupan di dunia ini. Dalam ayat tersebut ada beberapa syarat yang harus diataati dalam mencari rizki, yakni aspek kehalalannya baik dari perolehan, maupun saaat pendayagunaannya. Dari sini bisa kita tarik pengertian bisnis islami adalah 
serangkaian aktivitas bisnis dalam berbagai macam bentuknya yang tidak dibatasi kuantitasnya, namun dalam perolehan dan pendayagunaannya ada batasan - batasan antara halal dan haram, (Yusanto : $19: 1987$ )

\section{Perbedaan Bisnis Islami dan Non Islami.}

Pembicaraan seputar bisnis islam dan bisnis non islam adalah sangat terkait dengan faham perekonomian yang dijalaninya. Sistem ekonomi kapitalis dalam melakukan aktivitas bisnisnya mempunyai ciri dan prinsiptersendiri, yang berbeda dengan yang lain. Hal ini sebagaimana diungkapkan oleh Deliarnov, (1997), dalam bukunya, sejarah perkembangan dan pemikiran ekonomi yakni, Diantara sistem yang dikembangkan oleh kapitalis adalah

1. Seseorang dalam berbisnis dengan bebas memiliki harta yang diinginkan,serta menggunakan sumber - sumber ekonomi secara bebas.

2. Seseorang di perkenankan terjun dalam semua bidang perniagaan dan memperoleh sebanyak - banyaknya keuntungan tanpa adanya campur tangan pmerintah.

3. Dalam melakukan kegiatan bisnisnya, para pemilik modal akan banyak menikmati kebebasan yang lebih baik untuk mendapatkan hasil yang sempurna. Lanjut Deliamov, Dalam sistem ekonomi sosialis / komunis, saat melakukan aktivitas bisnisnya juga memiliki faham yang lain dengan kapitalis / liberal. Diantara faham yang dikembangkan oleh sosialis dalam melakukan aktivitas bisnis adalah :

1. Seluruh pendapatan yang peroleh dari usahanya adalah menjadi milik negara. Hak - hak individu yang dalam pandangan kapitalis bisa diperoleh dengan sebanyak - banyaknya, namun dalam faham ini sebaliknya yakniakan dipandu dan ada intertvensi dari negara.

2. Kebebasan individu di batasi dan bahkan dihapuskan sama sekali.

Adapun bisnis islam, adalah bisnis yang dikendalikan oleh nilai-nilai normatif ajaran Islam, baik dari cara perolehannya maupun cara pendayagunaannya (Yusanto, 1987). Islam dalam melakukan aktivitas bisnisnya, walaupun ada nilai - nilai kebebasan, nilai kepemilikan, dan kesamaan semuanya itu ada batas dan wilayah yang sudah ditentukan. Madjid Fakhri, dalam tulisannya Etika Dalam Islam (1995), ia katakan bahwa Bisnis islami yang dikendalikan oleh aturan halal dan haram, sama sekali beda dengan bisnis yang non islami. Dengan berlandaskan pada asas sekularisme yang bersendikan nilai - nilai materiil, bisnis non islami tidaklah memperhatikan halal - dan haram dalam merealisasikan tujuan bisnisnya.

Dari asas sekularisme inilah seluruh bangunan karakter non islami diarahkan pada sifat kebendaan, dan menafikan nilai - nilai ruhiyyah, serta keterikatan para pelaku bisnis denmgan aturan yang lahir dari dari nilai-nilai normatif transendental .Dengan karakter yang duimiliki ini bisnis islami akan hidup dan berkembang dalam 
lingkungan yang islami. Begitu juga isnis non islami, bisnis ini juga tidak akan hidup secara ideal dalam dalam sistem dan lingkungan yang Islami, kecuali ia merubah dirinya menjadi bisnis yang memperhatikan nilai - nilai islam. Dari sini jelas bahwa tumbuh dan berkembangnya bisnis tergantung pada sistem dan lingkungan yang ada. Untuk lebih jelasnya akan kita petakan karakteristik bisnis Islam dan non islam.

Dalam tulisan ini akan digambarkan pula sebagaimana ditulis Yusanto, yang memetakan karakteristik bisnia Islam Vs Non Islam.

\section{KARAKTERISTIK BISNIS ISLAMI VS NON ISLAMI}

\begin{tabular}{|l|c|l|}
\hline \multicolumn{1}{|c|}{ ISLAMI } & $\begin{array}{c}\text { KARAKTERISTIK } \\
\text { BISNIS }\end{array}$ & \multicolumn{1}{|c|}{ NON ISLAMI } \\
\hline $\begin{array}{l}\text { Aqidah Islam, nilai- } \\
\text { nilai transendental }\end{array}$ & Asas & $\begin{array}{l}\text { Sekularisme } \\
\text { (nilai-nilai materia) }\end{array}$ \\
\hline Dunia - akhirat & Motivasi & Dunia \\
\hline $\begin{array}{l}\text { Proft dan benefit } \\
\text { Non Materi / qimah) } \\
\text { Pertumbuhan, } \\
\text { keberlangsungan, } \\
\text { keberkahan }\end{array}$ & Orientasi & $\begin{array}{l}\text { Profit, pertumbuhan, } \\
\text { keberlangsungan }\end{array}$ \\
\hline $\begin{array}{l}\text { Tinggi, Bisnis adalah } \\
\text { bagaian dari ibadah }\end{array}$ & Etos kerja & $\begin{array}{l}\text { Tinggi, bisnisadalah } \\
\text { kebutuhan duniawi }\end{array}$ \\
\hline $\begin{array}{l}\text { Maju dan produktif, } \\
\text { konsekwensi keimanan, } \\
\text { manifestasi kemusliman }\end{array}$ & Sikap mental & $\begin{array}{l}\text { Maju, produktif, dan } \\
\text { konsumtif, sekaligus } \\
\text { aktualisasi diri }\end{array}$ \\
\hline $\begin{array}{l}\text { Cakap dan ahli dibidang } \\
\text { nya, konsekwensi dari } \\
\text { kewajiban seorang } \\
\text { muslim }\end{array}$ & Keahlian & $\begin{array}{l}\text { Cakap dan ahlidibidang } \\
\text { nya, konsekwensi dari } \\
\text { motivasi reward dan } \\
\text { punishment }\end{array}$ \\
\hline $\begin{array}{l}\text { Terpercaya dan ber- } \\
\text { tanggung jawab, tidak } \\
\text { menghalalkan segala } \\
\text { cara }\end{array}$ & Amanah & $\begin{array}{l}\text { Tergantung pada } \\
\text { kemauan individu, } \\
\text { menghalalkan segala } \\
\text { cara }\end{array}$ \\
\hline Halal & & Halal dan haram \\
\hline $\begin{array}{l}\text { Sesuai dengan akad } \\
\text { kerjanya }\end{array}$ & SDM & $\begin{array}{l}\text { Sesuai dengan akad } \\
\text { kerjanya pemilik modal }\end{array}$ \\
\hline
\end{tabular}




\begin{tabular}{|l|l|l|}
\hline Halal & \multicolumn{1}{|c|}{ Sumber daya } & Halal dan haram \\
\hline $\begin{array}{l}\text { Visi dan misi organisasi } \\
\text { terkait erat, dengan } \\
\text { penciptaan manusia } \\
\text { didunia }\end{array}$ & Manajemen Strategik & $\begin{array}{l}\text { Visi dan misi organisasi } \\
\text { ditetapkan berdasarkan } \\
\text { pada kepentingan } \\
\text { material belaka }\end{array}$ \\
\hline $\begin{array}{l}\text { Jaminan halal bagi } \\
\text { setiap masukan, proses } \\
\text { dan keluaran, mengede- } \\
\text { pankan produktivitas } \\
\text { dalam koridor syari'ah }\end{array}$ & Manajemen Operasi & $\begin{array}{l}\text { Tidak ada jaminan halal } \\
\text { bagi setiap masukan, } \\
\text { proses dan keluaran, } \\
\text { mengedepankan } \\
\text { produktiofitas dengan } \\
\text { koridor manfaat }\end{array}$ \\
\hline $\begin{array}{l}\text { Jaminan halal bagi } \\
\text { setiap masukan, proses } \\
\text { dan keluaran keuangan }\end{array}$ & Manajemen Keuangan & $\begin{array}{l}\text { Tidak ada jaminan halal } \\
\text { bagi setiap masukan, } \\
\text { proses dan keluaran } \\
\text { keuangan }\end{array}$ \\
\hline $\begin{array}{l}\text { Pemasaran daiam } \\
\text { koridor jaminan halal }\end{array}$ & Manajemen Pemasaran & $\begin{array}{l}\text { Pemasaran menghalalkan } \\
\text { segala macam cara }\end{array}$ \\
\hline $\begin{array}{l}\text { Sumberdaya profesional } \\
\text { dan berkepribadian } \\
\text { muslim, SDM adalah } \\
\text { pengelola bisnis, } \\
\text { bertanggung jawab } \\
\text { pada diri, majikan dan } \\
\text { Allah SWT. }\end{array}$ & Manajemen SDM & $\begin{array}{l}\text { SDM Profesional. SDM } \\
\text { adalah faktor produksi, } \\
\text { SDM bertanggung }\end{array}$ \\
\hline
\end{tabular}

\section{Perekonomian Modern.}

Ilmu ekonomi adalah suatu study ilmiah yang mengkaji bagaimana orang perorang atau kelompok menentukan pilihannya. Masalah - masalah pokok ekonomi mencakup pilihan - pilihan yang berkaitan dengan konsumsi, produksi, distribusi dan pertumbuhan sepanjang waktu. Ini semua dilakukan dalam rangka untuk memenuhi kebutuhan manusia yang tak terbatas dengan menggunakan sumber daya alam yang terbatas. Dalam perkembangan selanjutnya, pemikiran - pemikiran ilmu ekonomi melahirkan berbagai macam faham dan aliran dan sistem yang mengatur seseorang dalam berekonomi (Deliarnov, 1995).

Perekonomian modern adalah suatu pengembangan dari sistem perekomomian konvensional yang selama ini ada, (AM. Saifuddin : 1998). Namun ini bisa kita titik munculnya pekonomian modern ada yang mengungkapkan semenjak terjadinya revolusi industri $(1780-1840)$ yang ditandai dengan tenaga manusia diganti oleh 
serba mesin, maraknya ekspansi wilayah dunia bisnis, serta maraknya investasi di berbagai bidang sektor industri, (Hafidudin : 2002). Perekonomian modern ditandai pula dengan berbagai macam aktivitas (Anggito Abimanyu, 1985). Pertama, adanya pergerakan dan mobolitas modal semakin tidak memiliki "bendera "dan lebih berdasarkan perhitungan rasional ekonomis. Kedua, adanya investasi yang mendorong tumbuh dan menyuburnya perusahaan ke seluruh penjuru dunia. Ketiga, terjadinya pergeseran ekonomi yang akan memunculkan mega market dunia.

Dalam dunia perekonomian sejarah telah mengukir ada tiga sistem ekonomi yang pernah berjaya yakni kapitalisme, sosialisme, dan sistem negara sejahtera yang sekuler. Masing - masing telah mengalami revisi penting dari pemikiran aslinya seiring dengan problematika yang dihadapi. Walaupun sistem perekonomian senantiasa mengadakan revisi namun belum sesuai dengan apa yang dinginkan oleh sebagaian besar masyarakat, (AM. Saifuddin, 1998). Indikasinya adalah, tidak seimbangnya makro ekonomi, tidak meratanya distribusi pendapatan, laju inflasi yang kadang tidak menentu, distorsi harga yang tak terkendali. Adapun wacana pragmatis ekonomi modern lebih terfokus pada bagaimana meraih keuntungan, dengan menciptakan produk yang marketable, memasarkan produk yang pada gilirannya akan memberikan keuntungan riil bagi produsen, (Faisal, 2002).

Monzer Khaf (1995), Dalam bukunya yang sangat populer, Telaah analitik Sistem Ekonomi Islam, ia katakan beberapa perkembangan dalam peta ekonomi modern secara umum, masyarakat mengalami masa transisi dari industial economy menuju ke information economy. Jika dalam perekonomian industrial kontradiksi terjadi antara modal dan pekerja, dalam perkembangan perekonomian informatsi kontradiksi akan terjadi antara local dan cosmopolit. Dalam kondisi semacam ini sumberdaya informasi akan menjadi kunci utama dalam konfigurasi persaingan global. Keunggulan pihak cosmopolitans adalah ada pada penguasaan informasi sepenuhnya sebagai sumberdaya dalam persaingan bisnis, (Faisal : 2002).

\section{E. Bisnis Islam Dalam Perekonomian Modern.}

Seiring dengan kemajuan dalam bidang ilmu pengetahuan dan teknologi, ekonomi, politik dan budaya, dunia bisnis terus melaju dengan cepat. Dunia bisnis semakin mempenyai peranan sentral dalam keseluruhan kemajuan pada abad ini. Indonesia semenjak orde baru meletakkan prioritas pembangunan pada bidang perekonomian, dunia bisnis secara tidak langsung menjadi ujung tombak dalam pembangunan ekonomi demikian juga pada bidang - bidang yang lain (Hafiduddin, 2001). Sejalan dengan tekad orde baru untuk menuntaskan kemajuan bangsa Indonesia, bidang bisnis menjadi anak emas seluruh kebijakan pembangunan yang digulirkan pemerintah.

Dalam suasana seperti ini masyarakat juga semakin menyadari betapa pentingnya kegiatan bisnis bagi kemajuan dan perkembangan bangsa. Namun 
masuyarakat juga semakin peka, bagaimana kegiatan bisnis menjadi baik dan mengindahkan norma - norma, serta mengindahkan kepentingan dan kesejahteraan semua pihak (Keraf, 1995).

Terlebih lagi dalam kehidupan dunia yang semakin transparan seperti sekarang ini nilai-nilai normatif transendental secara tidak langsung ditantang untuk mampu mewujudkan diri dalam konteks yang lebih riil. Tuntutan ini nampaknya semakin logis disaat tatanan kehidupan didominasi faham hedonisme, sekularisme yang secara ekstrim hal ini bisa dipahami sebagi proses yang mengarah pada legitimasi peniadaan nilai normatif transendental diatas (UQ, Vol II, 1990).

Berbicara pada arus itulah bangunan dunia makna yang ada dalam konstruksi subyektifitas setiap individu secara fisiologis - kontemplatif sedikit banyak akan menentukan kecenderungan yang nantinya akan muncul dalam aktifitas bisnis mereka. Sebagai contoh adalah filsafat hedonisme (Suseno, 1989 : 113 - 134), faham ini berkeyakinan hendaknya manusia hidup sedemikian rupa sehingga ia dapat semakin bahagia. Pandangan hedonisme ini nampaknya paralel dengan faham egoisme, dimana Sony Keraf (1995) inti dari pandangan ini adalah tindakan setiap orang dalam hal apa saja pada dasarnya bertujuan untuk mengejar kepentingan pribadi, dan memajukan diri sendiri walaupun moralitas tidak mendampingi.

Kalau benar apa yang dikatakan keraf (1995), maka dalam dalam dunia perekonomian / bisnis, akan banyak diwarnai dengan berbagai macam ketidakadilan, ketimpangan sosial, kesewenangan dalam melakukan aktivitas ekonomi dan bisnis, yang akan membawa dampak negatif personal maupun komunal.

Sebagai illustrasi diabaikannya aspek normatif transendental dalam perekonomian ini akan nampak jelas, manakala kita melihat pemaparan diatas yakni sistem yang dikembangkan kapitalis dan sosialis dal;am aktivitas perekonomiannya. secara riil akan kita lihat paparan sekilas "prestasi" ekopnomi kapitalis Indonesia. Yakni mulai dari defisit Anggaran Belanja Negara (APBN), yang mencapai Rp. 53,8 T pada tahun 2001, hingga utang luar negeri yang mencapai 1700 trilyun pada awal tahun 2002. Dengan jelas kita lihat permainan harga saham yangh dilakukan oleh seorang kapitalis murni George soros pada awal 1997 yang ternyata berimplikasi terhadap perekonomian Indonesia terutama dalam sektor non riil. Dalam dunia perbankan penerapan sistem perekonomian / bisnis juga terlihat boroknya di saat terjadinya likuidiatas 16 bank oleh pemerintah dan 51 di bekukan, pada 1 November 1997. Belum lagi di Indonesia $70 \%$ uang beredar di Jakarta, namun hanya 200 orang saja yang menguasai $80 \%$ PDB Nnasional. Omset kelompok pengusaha prasetya Mulia sekita $80 \%$ RAPBN Indonesia, (Kompas, 2002).

Melihat realitas yang terjadi, perlu sekali para pelaku ekonomi, pelaku bisnis untuk tetap mengedepankan aktivitaas ekonomi haruslah paralel dengan kohesivitas komunikasi vertikal kepada Nya (Abdurrahim, 1982). Menurut Dawam Rahardjo 
(UQ. Vol II 1990 ) para pelaku ekonomi dan bisnis dalam menjalankan aktivitasnya harus dikendalikan oleh konsep tauhid ekonomi. Konsep tauhid dalam perekonomian ini akan melahirkan tiga hal penting:

1. Allah sebagai Al-Razzaq : Komitmen dapat melahirkan desakralisasi besar besaran dalam aktivitas ekonomi, sikap non egaliter, feodalisme hubungan patron - client dengan sendirinya akan tumbang dengan konsep bahwa Tuhan adalah satu - satu Dzat yang memberi rizki.

2. Konsep rizki yang ada mengisyaratkan pada acuan dasar sekalipun rizki Allah melimpah tak terbatas, tetaplah saja harus dipahami sebagai konteks bahwa Allah telah menetapkan takaran dan ukurannya. Sehingga manusia dalam melakukan aktivitas tidak bisa bebas melakukan eksploitasi lingkungan sekitarnya.

3. Dalam rangka mencari rizki kenikmatan sering memalingkan manusia dengan komitmen vertikal. Oleh karena itu konsep ini menawarkan alternatif keselarasan aktivitas dengan hubungan vertikal kepada Nya.

Stetmen ini nampak relevan dengan uraian makna kerja dalam perspektif teologi Islam menurut Muslim Abdurrahman (1995:266), menuutnya pembicaraan tentang aktivitas ekonomi / bisnis tidaklah bisa dilihat satu sisi saja, namun harus diletakkan dalam kontek aktualisasi manusia mencari harga diri. Dengan begitu secara teologis seharusnya kerja bukanlah suatu upaya mengumpulkan benda dan materi, namun lebih merupakan perwujudan diri dalam rangka mencari rildlo Allah SWT.

Adi Warman A. Karim (2001), dalam aktivitas ekonomi harus diwarnai dengan tiga hal yakni nilai - nilai Robbani, nilai Insani, dan nilai Wasathi. Nilai Robbani dalam aktivitas ekonomi adalah mempunyai dua konotasi makna, pertama, hak untuk mengatur dan menetapkan hukum - hukum ekonomi ini hanya milik Allah, kedua, ekonomi adalah sarana bukan tujuan. Aktivitas ekonomi dijalankan dalam rangka membantu seorang muslim untuk memenuhi perintah Allah dan mendekatkan diri kepada - Nya. Nilai Insani, membawa maksud perhitungan kemanusiaan sebagai asas dan prinsip ekonomi, manusia tidak boleh dikorbankan demi materi, namun sebaliknya materi dikorbankan demi manusia. Nilai Ekonomi Wasathi, artinya peerekonomian / bisnis harus dilakukan dengan moderat. Yakni kalau kapitalis menjadikan individu sebagai dasar selurtuh aktivitas ekonomi dan sosialis menjadikan kepentingan negara sebagai dasar seluruh aktivitas ekonomi, maka islam mengambil jalan pertengahan yang menyeimbangkan antara kepentingan individu dan negara sehingga tercapailah kehidupan yang harrmonis.

Dengan mengangkat nilai - nilai normatif transendental dalam dunia bisnis, nampaknya bisa kita jadikan referensi utama kembali, dalam perekonomian modern ini. Yang ditandai dengan maraknya infestasi diberbagai sektor, ekspansi pasar, 
penciptaan persaingan produk demi mendapatken keuntungan riil dari bisnis yang dilakukan dll. Bahkan ditengah - tengah munculnya patologi globalisasi ekonomi yang menurut Pialang (1998 : 34 - 37), mengusulkan suatu paradigma yang berpandangan jauh ke depan dan bersifat beyon economic, yang memiliki sifat integratif, kualitatif, perhatian yang besar tehadap komunitas yang berpijak pada norma - norma yang yang berlaku pada masyarakat.

\section{F. Penutup}

Dalam pemaparan diatas mengenai “ Menggagas Bisnis Islam Dalam Perekonomian Modern" penulis dapat simpulkan sebagai berikut. Pertama, Islam sangat memperhatikan aspek - aspek normatif transendental dalam melakukan kegiatan perekonomian / bisnis, untuk mewujudkan keadilan, keseimbangan, dan ketenteraman dalam masyarakat. Kedua. Sistem bisnis yang diterapkan ala kapitalis / liberal dan komunis / sosialis sangat merugikan masyarakat luas. Ketiga, Berbisnis / berekonomi bukan semata - mata mencari harta dalam hidupnya, namun harus diletakkan dalam konteks manusia mencari harga diri, sehingga dalam melalakukan kegiatan bisnis senantiasa bersandar dan berkeyakinan bahwa, Allah sebagai AlRozzak, rizki manusia sudah ada ukurannya, ni'mat dari perolehan rizki sebagai sarana kedekatannya dengan YMK.

\section{Daftar Pustaka}

Abdul Rahim, Muhammad Uimadudin, Kuliah Tauhid, Pustaka, Bandung, 1982.

Amin, M.Masyhur, Moralitas Pembangunan, LKPSM, Yogyakarta, 1994

Anoraga, Panji, Manajemen Bisnis, Rineka Cipta, Jakarta, 1997

Basyir, Azhar, Ahmad, Sistem Ekonmomi Islam, UGM , Press 1981.

Keraf, Sony, Etika Bisnis, Kanisius, Yogyakarta, 1995

Kirana, Andi, Etika Manajemen, Penerbit Andi, Yogyakarta, 1997

Piliang, Yasraf, Amir, Sebuah Dunia yang di Lipat, Mizan, Bandung, 1994

Prately, Petter, Etika Bisnis, Andi Ofset, Yogyakarta, 1997

Qordlowi, Yusuf, Norma dan Etika Ekonomi Islam, GIP, Jakarta, 1997

Rahardjo, Dawam, Ensiklopedi Al Qur - an Tafsir, Sosial Berdasarkan Konsep Konsep Kunci, Paramadina Jakarta, 1995

Sasono Adi, Dkk Solusi Islam atas Problematika Ekonomi Umat, GIP, Jakarta, 1998. 